\title{
Benzoylarginine Peptidase and Iminopeptidase Profiles of Treponema denticola Strains Isolated from the Human Periodontal Pocket
}

\author{
Kauko K. Mäkinen, Salam A. Syed, Pirkko-Liisa Mäkinen, and Walter J. Loesche \\ School of Dentistry, University of Michigan, Ann Arbor, Michigan, USA
}

\begin{abstract}
Seven clinical isolates and the ATCC strain 35405 of Treponema denticola, obtained from human periodontal pockets, were studied for peptidase activity with several chromogenic compounds as substrates. The cell sonicates of all strains hydrolyzed phenylazobenzyloxycarbonyl-L-prolyl-L-leucyl-glycyl-L-prolyl-D-arginine (a collagenase substrate), azocasein, and the 2-naphthylamines of L-proline, L-hydroxyproline, L-pyrrolidine, and benzoyl-L-arginine, but the rates of hydrolysis varied considerably from strain to strain. Fast protein liquid chromatography on gel and anion exchange columns revealed further biochemical differences between the strains. The ATCC strain consistently produced several proline iminopeptidases, whereas four of the clinical isolates yielded high and three yielded low iminopeptidase activity. The ATCC strain and six clinical isolates displayed high benzoylarginine peptidase activity. The use of $N$-L-prolyl-2-naphthylamine as substrate revealed more differences between the strains than other substrates. The substrate specificity of the enzymes discovered suggests that they may be important for the nutrition of the organism or in the protection of the organism against chemical defense factors present in the gingival pocket.
\end{abstract}

Treponema denticola and other treponemes have been shown to be associated with the human periodontal disease $[1,7-9,17]$. The nutritional requirements of these organisms can be expected to be reflected in their enzyme profile; the strains of $T$. denticola isolated from the subgingival plaque synthesize proteolytic enzymes $[12,15,16]$ that may be involved in the degradation of several host proteins and peptides present in the periodontal pocket. Although it is known that $T$. denticola possesses fibrinolytic activity [15], a gelatinase and a peptidase activity against $N \alpha$-benzoyl-DL-arginyl-2-naphthylamine [16], virtually nothing is known about the number and types of other proteolytic enzymes produced by $T$. denticola. An aminopeptidase of $T$. phagedenis was recently studied by Takahashi et al. [20]. The purpose of this article was to investigate the properties of proteolytic enzymes produced by seven strains of $T$. denticola isolated from the subgingival plaque of periodontitis patients, and to compare the data obtained with those of $T$. denticola ATCC 35405 , which was also originally isolated from human periodontal pockets [4]. Because the enzymes were isolated by using $N \alpha$-benzoyl-L- arginyl-p-nitroaniline (BAPNA) and $N$-L-prolyl-2naphthylamine (pro-2NA) as substrates, the enzymes were designated as benzoylarginine peptidases and proline iminopeptidases, respectively.

\section{Materials and Methods}

Source and treatment of Treponema denticola strains. Seven strains $\left(\mathrm{Al}_{2}\right.$, Spira, Corha, $\mathrm{H}_{22}$, Sim, Myr and $\left.\mathrm{H}_{1}\right)$ of T. denticola were isolated from the subgingival plaque of periodontitis patients. The $T$. denticola ATCC 35405 reference strain had originally been isolated from human periodontal pockets [4]. The cells of all eight strains were grown aerobically in screwcapped bottles in $100 \mathrm{ml}$ of Tryptone-heart infusion-yeast extract broth as described elsewhere [12] and harvested after $48 \mathrm{~h}$ growth by centrifugation for $10 \mathrm{~min}$ at $4500 \mathrm{~g}$. The cells were washed three

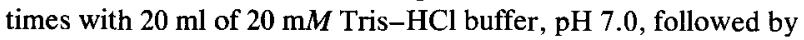
final suspension in $10 \mathrm{ml}$ of buffer. The suspensions were treated for $20 \mathrm{~s}$ with a Sonifier Cell Disrupter (Model W 1850D; Branson Sonic Power Company, Plainview, New York) with the instrument setting of 7 and a probe with an end diameter of $3 \mathrm{~mm}$. The resultant sonicates were centrifuged as above. The supernatant fluids were used as starting material in the purification of the enzymes.

Chromatography and enzyme purification. The chromatographic separations were performed with a complete Pharmacia fast pro- 
Table 1. Specific peptidase activities of sonicates of Treponema denticola isolated from human subgingival plaque ${ }^{a}$

\begin{tabular}{|c|c|c|c|c|c|c|}
\hline \multirow[b]{2}{*}{ Strain } & \multicolumn{4}{|c|}{ Substrate } & \multirow[b]{2}{*}{ Azocasein $^{c}$} & \multirow[b]{2}{*}{$\mathrm{PLGPA}^{d}$} \\
\hline & Pro- $2 \mathrm{NA}^{b}$ & OH-Pro-2NA ${ }^{b}$ & Pyr-2NA ${ }^{b}$ & $\mathrm{BANA}^{b}$ & & \\
\hline ATCC 35405 & 450 & 36 & 29 & 136 & 9.7 & 160 \\
\hline Myr & 67 & 3 & 26 & 134 & 7.8 & 130 \\
\hline Sim & 400 & 9 & 34 & 125 & 16.5 & 130 \\
\hline Corha & 200 & 13 & 15 & 75 & 6.4 & 160 \\
\hline $\mathrm{H}_{\mathrm{t}}$ & 360 & 9 & 12 & 8 & 6.7 & 110 \\
\hline Spira & 410 & 10 & 13 & 640 & 7.3 & 170 \\
\hline $\mathrm{AL}_{2}$ & 74 & 5 & 31 & 755 & 9.4 & 120 \\
\hline $\mathrm{H}_{22}$ & 43 & 10 & 35 & 946 & 7.8 & 120 \\
\hline
\end{tabular}

a The cell sonicates were made as deseribed in Materials and Methods. After sonication, the preparations were concentrated tenfold. The figures shown were obtained from those concentrates.

${ }^{b}$ The specific activities are given in $\mu \mathrm{mol} \mathrm{min}^{-1} \mathrm{mg}^{-1}\left(\times 10^{5}\right)$. Pyr-2NA $=N$-L-pyrrolidonyl-2NA.

${ }^{c}$ In enzyme units $\mathrm{min}^{-1} \mathrm{mg}^{-1}\left(\times 10^{3}\right)$. One unit corresponds to the amount of the enzyme producing an $\mathrm{A}_{366}$ of 0.1 in 1 min in $0.5 \mathrm{M}$ Tris- $\mathrm{HCl}\left(\mathrm{pH} \mathrm{7.0,} \mathrm{containing} 10 \mathrm{mM} \mathrm{CaCl}_{2}\right)$. Tested at $37^{\circ} \mathrm{C}$ with a substrate concentration of $6.7 \mathrm{mg} / 0.6 \mathrm{ml}(=$ volume of reaction mixture).

${ }^{d}$ In $\mu \mathrm{mol} \mathrm{min}^{-1} \mathrm{mg}^{-1}\left(\times 10^{3}\right)$.
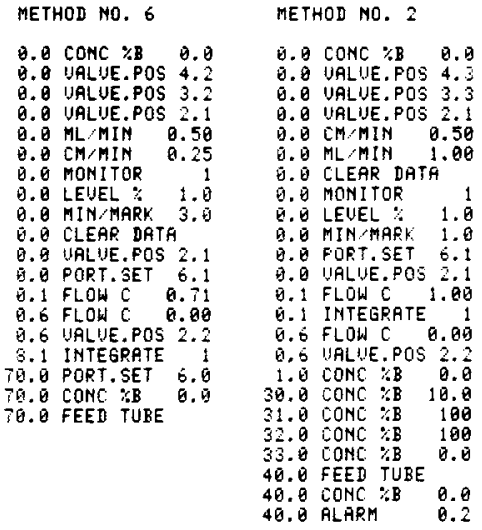

Fig. 1. FPLC programs used in the separation of Treponema denticola benzoylarginine peptidases and iminopeptidases on a gel column (method 6) and an anion exchange column (method 2). The duration of the separations was $70 \mathrm{~min}(\operatorname{method} 6)$ and 40 $\min (\operatorname{method} 2)$. The injected sample volumes were $0.4 \mathrm{ml}$ in both programs, but the injection rates and flow rates were two times higher in method 2 than in method 6.

tein liquid chromatograph (FPLC; Pharmacia, Piscataway, New Jersey), which was operated at $22^{\circ} \mathrm{C}$. The protein was monitored at $280 \mathrm{~nm}$, and the equipment included a Superose $12 \mathrm{HR} 10 / 30$ gel column and a Mono Q HR5/5 anion exchange column [12]. The samples injected into the system were clarified with ACRO LC13 $0.2 \mu$ filters (Gelman Sciences, Ann Arbor, Michigan) and concentrated with Centricon-10 or Centricon-30 membranes (cutoff 10,000 and 30,000 molecular weight, respectively; Amicon, Lexington, Massachusetts). The partial purification of the enzymes of $T$. denticola ATCC 35405 with the FPLC system was described elsewhere [12], and essentially the same procedure was followed here. The FPLC programs used in the automated separations of the enzymes on the gel and anion exchange columns are shown in Fig. 1. Except for the FPLC separations, each of which was completed in $40-70 \mathrm{~min}$, all purification steps were performed at $+4^{\circ} \mathrm{C}$.

Chemical methods. The enzyme activities were determined using phenylazobenzyloxycarbonyl-L-prolyl-L-leucylglycyl-L-prolylD-arginine (PLGPA, a collagenase substrate) [21], azocoll [3, 13], azocasein [19], elastin-orcein [18], serum albumin [5], $N$-aminoacyl-2-naphthylamines (2NA) [11], $N \alpha$-benzoyl-DL-arginyl-2naphthylamine (BANA) [11], and $N \alpha$-benzoyl-L-arginyl- $p$-nitroaniline (BAPNA) [6, 10] as substrates. The protein concentrations were assayed with the Bio-Rad assay system [2]. The source of substrates and other details of the assay mixtures are mentioned elsewhere [12].

\section{Results}

Specific activities. Table 1 shows that the ability of $T$. denticola strains to hydrolyze certain peptidase substrates (pro-2NA, OH-pro-2NA, and BANA) varied greatly, whereas other substrates (pyr-2NA, azocasein, and PLGPA) were hydrolyzed at rather similar rates. The ATCC strain was a good source of proline iminopeptidase activity and also displayed high activity toward all other substrates shown in Table 1 . Three strains $\left(\mathrm{Myr}, \mathrm{Al}_{2}\right.$, and $\left.\mathrm{H}_{22}\right)$ of the seven other strains studied were poor producers of proline iminopeptidase(s) under these conditions. With the exception of Corha and $\mathrm{H}_{1}$, all other strains produced BANA-hydrolyzing enzyme(s) in high quantities. In spite of the relatively high rate of hydrolysis of PLGPA (which can be regarded as an endopeptidase substrate), none of the strains studied showed measurable hydrolysis of elastin-orcein, azocoll, and serum albumin. 


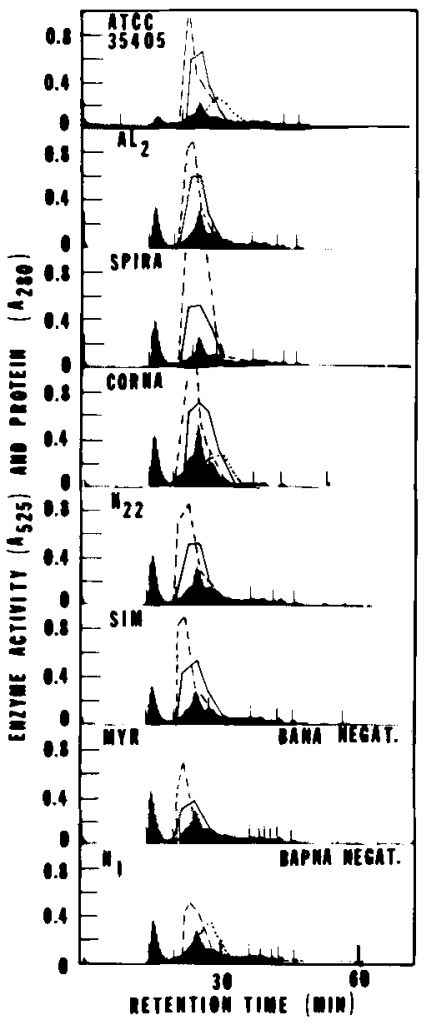

Fig. 2. FPLC on the gel column of Treponema denticola peptidases hydrolyzing pro-2NA and BAPNA. In three cases (ATCC 35405 , Corha, and $\mathrm{H}_{1}$ ) the separation of enzymes hydrolyzing $\alpha$ aspartyl-2NA is shown. The FPLC program used is shown in Fig. 1. The elution buffer was $0.1 M$ Tris- $\mathrm{HCl}$, pH 7.0, containing $10 \mathrm{mMCaCl}$ and $50 \mathrm{mM} \mathrm{NaCl}$. The flow rate was $0.5 \mathrm{ml} / \mathrm{min}$, and fractions of $1.0 \mathrm{ml}(2 \mathrm{~min})$ were collected. The fractions showing activity toward BAPNA and pro-2NA were pooled, concentrated about fivefold, and injected into the Mono $Q$ anion exchange column (Fig. 3). ----, pro-2NA; - , BAPNA; ....., $\alpha$-aspartyl-2NA; and black areas, protein.

FPLC of benzoylarginine peptidases and iminopeptidases. The FPLC separations disclosed considerable differences between the strains studied when pro-2NA and BAPNA were used as substrates (Figs. 2 and 3). However, the gel column produced essentially similar fractionation of proteins (Fig. 2). All gel separations were also tested with BANA, which was hydrolyzed by an enzyme or a group of enzymes with a similar retention time as that of the enzyme(s) hydrolyzing BAPNA, with the exception that Myr showed virtually no activity toward BANA and that $\mathrm{H}_{1}$ showed no activity toward BAPNA. These results indicate that, in spite of the involvement in BAPNA and BANA, an identical aromatic substituent blocking the $\alpha$-amino function of the substrates, these molecules may have been

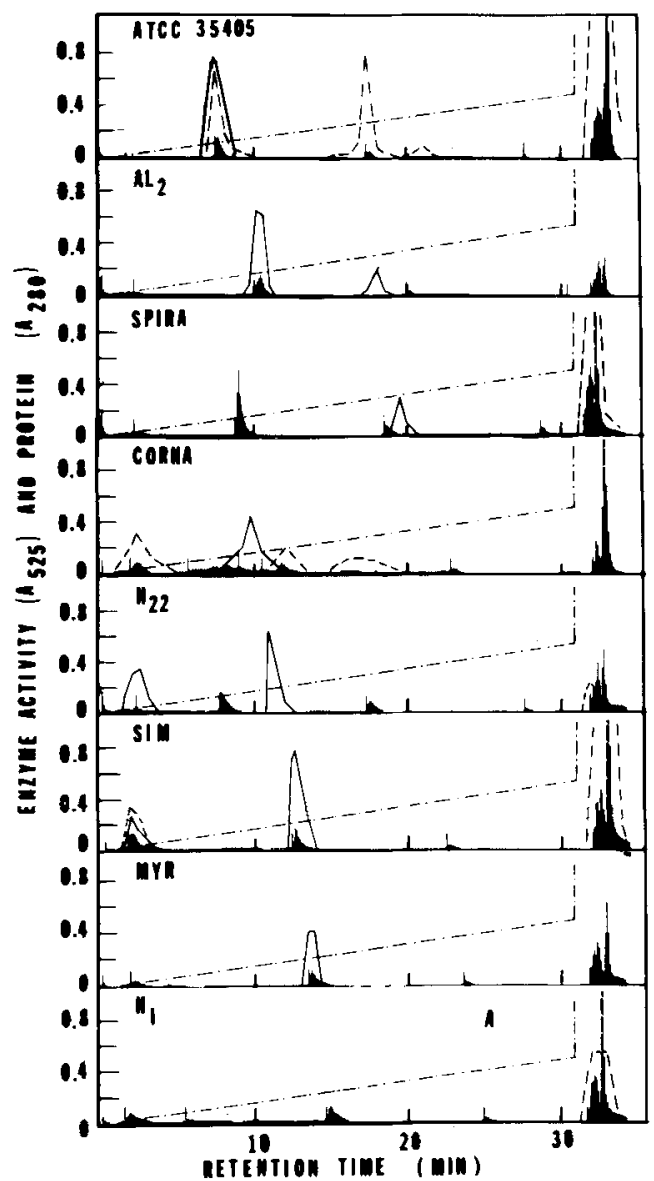

Fig. 3. FPLC on the anion exchange column of Treponema denticola peptidases hydrolyzing pro-2NA and BAPNA. The samples were obtained from the FPLC separations on the gel column (Fig. 2); the chromatographic program is shown in Fig. 1. The elution buffer was $10 \mathrm{mM}$ Tris- $\mathrm{HCl}, \mathrm{pH} 7.0$, containing $10 \mathrm{mM}$ $\mathrm{CaCl}_{2}$ and a linear $\mathrm{NaCl}$ gradient from 0 to $0.1 \mathrm{M}$. The $\mathrm{NaCl}$ concentration was increased after $31 \mathrm{~min}$ to $1.0 \mathrm{M}$. The flow rate was $1.0 \mathrm{ml} / \mathrm{min}$, and fractions of $1.0 \mathrm{ml}$ were collected. ----, pro-2NA; - - , BAPNA; -.-.-.--, NaCl gradient; and black areas, protein.

hydrolyzed, at least in some strains, by separate enzymes. ATCC 35405 , Corha, and $\mathrm{H}_{1}$ were also tested with $\alpha$-aspartyl-2NA, which was hydrolyzed by an enzyme the retention time of which corresponded to a molecular weight of 29,000 , compared with the molecular weight estimated for the enzyme(s) hydrolyzing pro-2NA $(>100,000)$ and BAPNA $(45,000)$, respectively (Fig. 2$)$. The iminopeptidases were fractionated too close to the void volume for more accurate molecular weight estimation. The reference proteins used were mentioned elsewhere [12].

FPLC on the anion exchange column revealed 
still more pronounced differences between the $T$. denticola strains studied (Fig. 3). The ATCC strain revealed three major proline iminopeptidase-like enzymes; the other strains did not possess this many iminopeptidases (Corha did show three enzymes with iminopeptidase activity, but these activities were always very low compared with those of ATCC 35405, and they eluted at different elution times). Although all strains displayed activity toward pro-2NA before anion exchange chromatography, the strains $\mathrm{Al}_{2}, \mathrm{Myr}, \mathrm{H}_{22}$, and $\mathrm{H}_{1}$ showed little or no iminopeptidase activity after the Mono Q separations. This may have resulted from different stability of the enzymes involved. It was difficult to observe any consistent similarities between the strains in Fig. 3, apart from the fact that the final 1.0 $M \mathrm{NaCl}$ concentration of the eluant resulted in the appearance of one major protein peak at the end of the runs. In five cases out of eight, this high protein peak was associated with a proline iminopeptidase peak with varying activity (ATCC 35405, Spira, $\mathrm{H}_{22}$, Sim, and $\mathrm{H}_{1}$ ).

Characterization of enzymes. Some of the enzymes revealed by FPLC on the anion exchange column (Fig. 3) were characterized as follows: The $\mathrm{pH}$ optimum in the hydrolysis of pro-2NA by all enzymes with proline iminopeptidase activity was 7.2-7.5 (in $0.1 M$ Tris- $\mathrm{HCl}$ buffer). In the same buffer, the $\mathrm{pH}$ optimum in the hydrolysis of BAPNA by all enzymes displaying measurable activity toward this substrate was about 9.0 or slightly higher. With this substrate no distinct $\mathrm{pH}$ maximum was attained in Tris-HCl buffer; a plateau was usually obtained between pH 8.5 and 9.0. In the same buffer, however, the hydrolysis of BANA showed a clear maximum at $\mathrm{pH}$ 7.5. Thus, the substrate with the bulkier aromatic ring system (connoting the naphthylamine residue) produced a less alkaline $\mathrm{pH}$ optimum (all substrates were tested at $0.167 \mathrm{mM}$ ).

Some of the enzymes were obtained in quantities sufficient for the determination of the value of the Michaelis-Menten constant. Using three different plotting methods [12], the ATCC 35405 proline iminopeptidase with a retention time of $32 \mathrm{~min}$ (Fig. 3) gave a value of $0.05 \pm 0.02 \mathrm{mM}(\mathrm{n}=4)$ in $0.1 \mathrm{M}$ Tris- $\mathrm{HCl}$ buffer, $\mathrm{pH}$ 7.0. An enzyme obtained from Corha (retention time, 16-18 min; Fig. 3) gave a value of $0.03 \pm 0.01 \mathrm{~m} M(\mathrm{n}=3)$. The kinetics of these enzymes followed the normal MichaelisMenten behavior with no significant substrate inhibition. In the above buffer, $0.167 \mu M p$-chloromercuribenzoic acid caused a total inactivation of proline iminopeptidases eluted with $1.0 \mathrm{M} \mathrm{NaCl}$ (Fig. 3). The enzymes obtained from the anion exchange separations were stored at $-20^{\circ} \mathrm{C}$. At this temperature the iminopeptidases gradually lost most of their activity (in 2 months), whereas the enzymes hydrolyzing BANA and BAPNA maintained their original activity for at least 2 months.

\section{Discussion}

Fast protein liquid chromatography turned out to be a suitable analytical and separative method that produced reproducible results in $T$. denticola enzymes, provided that the manufacturer's instructions were followed concerning regular cleaning of the columns and that the elution buffers were identical from separation to separation. In fact, it was found that certain combinations of linear $\mathrm{NaCl}$ gradients produced even more effective separation of enzymes than shown in Fig. 3. It is possible that direct anion exchange chromatography on Mono $Q$ columns with well-dialyzed sonicates of $T$. denticola and other microorganisms could be exploited as an instrument in taxonomic and other comparative, biochemical identification studies. This FPLC technique can be expected to be useful in classification of Treponema species and strains, and it would thus complete the information obtained from traditional microscopic and biochemical tests.

The present results can be examined in light of the conception of the so-called "negativity" of certain T. denticola strains as determined with BANA, BAPNA, and related substrates. Consequently, although simple color tests of $T$. denticola cultures may indicate that such strains as $\mathrm{Myr}$ and $\mathrm{H}_{1}$ are "trypsin negative" (connoting that BANA or BAPNA were not hydrolyzed), the present biochemical experiments indicate that these strains do exhibit activity toward those substrates. It is doubtful whether the term "trypsin-like" and the practice of comparing spirochete (or other microbial) peptidases with trypsin are useful at all. Such comparisons should rather relate to more precise chemical classification of peptidases [14]. Although the purpose of this study was not to carry out chemical characterization of Treponema enzymes, it appears that the proline iminopeptidases eluted with $1.0 \mathrm{M}$ $\mathrm{NaCl}$ (Fig. 3) in five strains may be similar enzymes and identical with the one described in our previous publication [12]. Likewise, the BAPNA-hydrolyzing peptidase described by us in another oral strain of $T$. denticola [16] most likely corresponds to one of the BAPNA-hydrolyzing enzymes eluted at low 
$\mathrm{NaCl}$ concentrations (Fig. 3). The above $T$. denticola iminopeptidase was found to be an SH-peptidase with no detectable dependence on active serine residues or metal cations [12]. The activity of this enzyme appeared to depend, however, on tyrosyl (or histidyl) and carboxyl groups. The BAPNA-hydrolyzing enzyme was unaffected by SH-reagents and EDTA, but it was inhibited by diisopropyl phosphofluoridate, a reagent that has been used in probing active seryl residues of enzymes [16].

These studies showed that the eight strains of $T$. denticola, all isolated from the human periodontal pocket, differed biochemically from one another, as evidenced by the specific activity determinations and FPLC separations. Studies are in progress at this laboratory to determine which of the present enzymes are true iminopeptidases or true endopeptidases.

It is also possible that these clinical isolates could include species other than $T$. denticola, since no DNA studies have been performed on these organisms. It is possible that FPLC enzyme and protein profiles could be used along with DNA studies to elucidate this question. The ability of all strains of $T$. denticola to hydrolyze PLGPA, a collagenase substrate, suggests that specific endopeptidases are produced by this organism. Our results indicate that similar enzymes are present in the subgingival plaque of periodontitis patients (unpublished data).

\section{ACKNOWLEDGMENT}

This work was supported by NIDR grant DE02731-19.

\section{Literature Cited}

1. Armitage GC, Dickinson WR, Jenderseck RS, Levine SM, Chambers DW (1982) Relationship between the percentage of subgingival spirochetes and the severity of periodontal disease. J Periodontol 53:550-556

2. Bradford MM (1976) A rapid and sensitive method for the quantitation of microgram quantities of protein utilizing the principle of protein-dye binding. Anal Biochem 72:248-254

3. Chavira R Jr, Burnett TJ, Hageman JH (1984) Assaying proteinase with azocoll. Anal Biochem 136:446-450

4. Cheng S-L, Chan ECS (1983) The routine isolation, growth and maintenance of the intermediate-size anaerobic oral spirochetes from periodontal pockets. J Periodont Res 18:362-368

5. Church FC, Porter DH, Catignani GL, Swaisgood HE (1985) An $o$-phthaladehyde spectrophotometric assay for proteinases. Anal Biochem 146:343-348

6. Erlanger BF, Kokowsky N, Cohen W (1961) The preparation and properties of two new chromogenic substrates of trypsin. Arch Biochem Biophys 95:271-278

7. Listgarten MA, Levin S (1981) Positive correlation between proportions of subgingival spirochetes and motile bacteria and susceptibility of human subjects to periodontal deterioration. J Clin Periodontol 8:122-138

8. Loesche WJ, Laughon BB (1982) Role of spirochetes in periodontal disease. In: Genco RJ, Mergenhagen SE (eds) Hostparasite interactions in periodontal disease. Washington $\mathrm{DC}$ : American Society for Microbiology, pp 62-75

9. Loesche WJ, Syed SA, Schmidt E, Morrison EC (1985) Bacterial profiles of subgingival plaques in periondontitis. $J$ Periodontal 56:447-456

10. Mäkinen KK, Mäkinen P-L (1971) Effect of sodium chloride on substrate constant and maximum velocity in the enzymic hydrolysis of $\mathrm{N}$-L-aminoacyl-2-naphthylamines and $\mathrm{N}$-Laminoacyl-p-nitroanilines. Acta Chem Scand 25:969-975

11. Mäkinen KK, Mäkinen P-L (1978) Purification and characterization of two human erythrocyte arylamidases preferentially hydrolysing $N$-terminal arginine or lysine residues. Biochem J 175: 1051-1067

12. Mäkinen KK, Syed SA, Mäkinen P-L, Loesche WJ (1986) Characterization of proline iminopeptidases of Treponema denticola ATCC 35405, a human oral spirochete. J Periodontal (in press)

13. Moore GL (1969) Use of azo-dye-bound collagen to measure reaction velocities of proteolytic enzymes. Anal Biochem 32:122-127

14. Neurath $H$ (1984) Evolution of proteolytic enzymes. Science 224:350-357

15. Nitzan D, Sperry JF, Wilkins TD (1978) Fibrinolytic activity of oral anaerobic bacteria. Arch Oral Biol 23:465-470

16. Ohta K, Mäkinen KK, Loesche WJ (1986) Purification and characterization of an enzyme from Treponema denticola capable of hydrolyzing synthetic trypsin substrates. Infect Immun (in press)

17. Olsen I (1984) Attachment of Treponema denticola to cultured human epithelial cells. Scand J Dent Res 92:55-63

18. Sachar L, Winter KK, Sicher N, Frankel S (1955) Photometric method for estimation of elastase activity. Proc Soc Exp Biol Med 90:323-326

19. Seppä HE, Järvinen M (1978) Rat skin main neutral protease: purification and properties. J Invest Dermatol 70:84-89

20. Takahashi T, Asari K, Sato N, Yamaya S, Sugahara T (1985) Purification and properties of an aminopeptidase from Treponema phagedenis. Curr Microbiol 12:283-288

21. Wünsch E, Heidrich HG (1963) Quantitative Bestimmung der Kollagenase. Z Physiol Chem 333:149-151 